\title{
Application of Logistic Differential Equation to Investigate The Extent of Emphasizing Stimulus Variation in Mathematics Instruction
}

\author{
Chinedu Obasi * \\ Department of Mathematics, Alvan Ikoku Federal College of Education, Owerri Imo State, Nigeria \\ "Corresponding Author, obasi1212@gmail.com
}

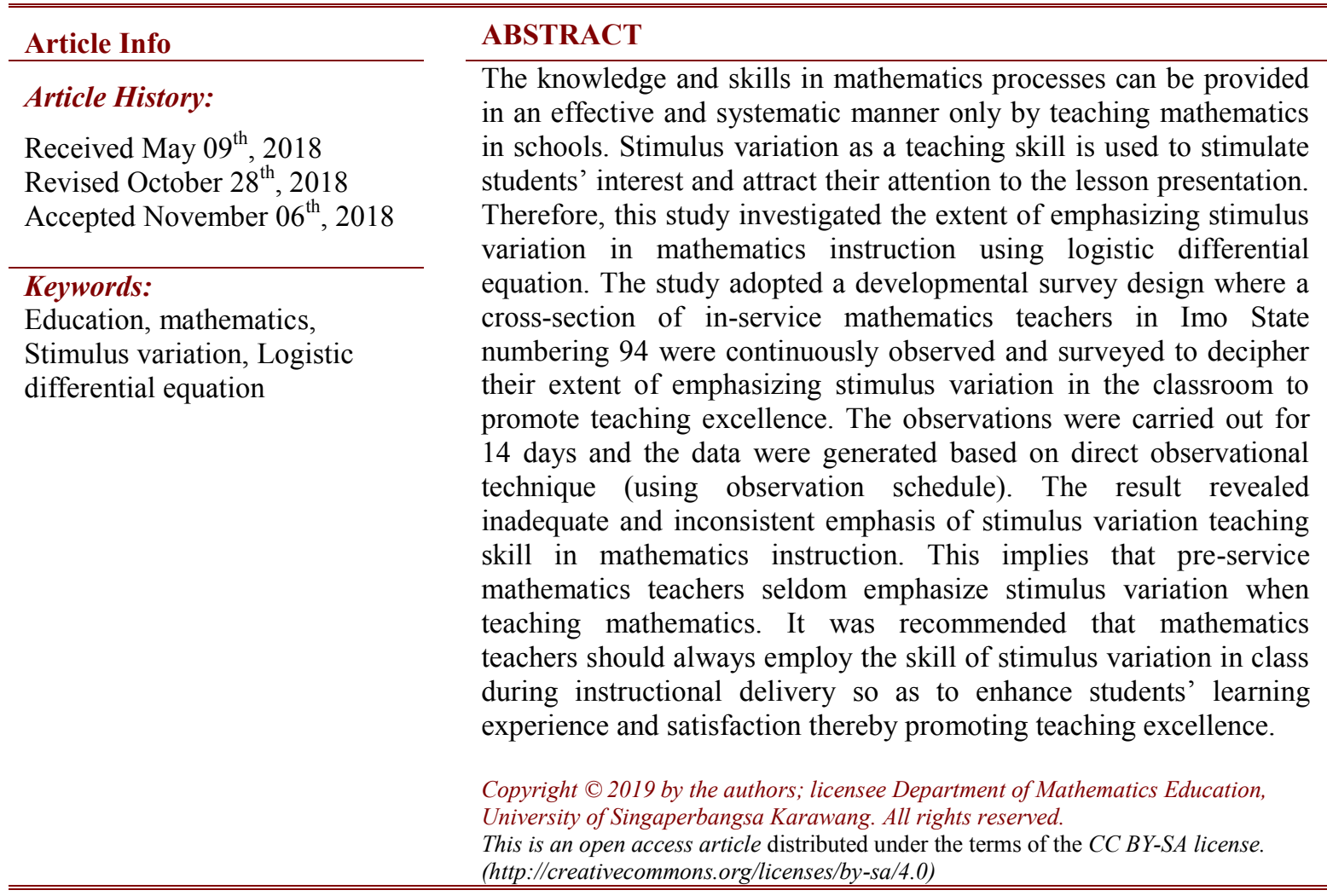

\section{INTRODUCTION}

Education in any normal society is accepted as an instrument to power, prestige, survival, greatness and advancement for men and women. It is the process of acquiring knowledge, skills and other capabilities. Education makes an individual to become an asset and not a liability to the society. The individual develops physically, mentally, socially, emotionally and spiritually from birth throughout a life time. It is hardly inconceivable to imagine a learning process without education. For instance, how and where would a professor transmit his knowledge to students? How can the innermost recesses of a teacher be tapped by students? Any serious response to these questions may probably x-ray the importance of higher education and its contributions to educational system in Nigeria (Jaja, 2013).

Education is the bedrock of any national development either in the developed, developing or under-developed nation. Any scientific education which does not commence with mathematics is said to be defective in its foundation. Mathematics is related to many things in human's daily life and its study provides students with certain basic life skills and processes that prepare them to be productive members of the society. Azuka (2015) 
emphasized that mathematical skills relevant to a wide range of analytical, technological, scientific, security, political and economic applications hence the solid foundation in mathematics prepare one for other educational and professional challenges.

Mathematics is an important core subject in the secondary school curriculum. The subject is indispensable to national goals and objectives hence it is made compulsory for every student in both primary and secondary schools. This great emphasis is placed upon the learning of mathematics because of its utility to the individual as well as to the nation at large (Ojo \& Ojo in Unamba \& Obasi, 2011). The knowledge and skills in mathematics processes can be provided in an effective and systematic manner only by teaching mathematics in schools (Kulbir, 2006). Despite its utility, mathematics has been one of the subjects which Nigerian students especially at secondary schools level develop dislike for and likewise perform poorly (Odili, 2006). Results of candidates who sat for both the West African Examinations Council's (WAEC's) and National Examinations Council's (NECO's) Senior School Certificate Examination (SSCE) in recent times show that most school leavers performed poorly in mathematics (WAEC, 2016; NECO, 2016). The big question is, "what can be done to promote teaching excellence in mathematics so as to enhance students' learning experience and satisfaction?

Kolawole \& Oluwatayo (2004) stated that the more knowledge of mathematical concepts with the corresponding knowledge of their application to real life seems to be deteriorating. To develop scientifically, technologically, economically, politically depends on the manpower the country has acquired. This man power includes the mathematics teachers among others. To develop manpower resources means to produce competent human resources. The significant fact in the development of manpower resources refer to the competences and level on which these competences are imparted which depend largely on those who develop these competencies. The people that impart knowledge are referred to as teachers. The teacher is someone that is trained and certificated to teach. He is regarded as the key player in the entire educational process, the mirror in the society and the father of knowledge (Tali, Mbwas, \& Abe, 2012). He is the converter of raw materials to finished products through a systematic procedure in the school which is considered as a human factory. According to Okoye (2007), a teacher does these in various capacities such as educator, adviser, instructor, lecturer, counselor, guidance, researcher, innovator and leader. Onocha (2013) observed that teachers are a critical factor in delivering qualitative education. Therefore, for this purpose, there is need for highly competent teachers for imparting those competences. As a result, teachers imparting the competences should have the capability to perform their tasks efficiently.

In addition, Onocha (2013) posited that teachers must be well informed and highly resourceful to meet the demand of teaching profession. Therefore, there is need for quality training that can enhance effectiveness which can only be acquired through teacher education program. Onocha referred to teacher education or preparation as the policies and procedures that are designed to equip teacher trainees with the knowledge, skills, values, habits, attitudes, behaviors and skills they need for effective performance of their duties.

Despite the effort of the government on the development of mathematics teaching and provision of opportunities for the improvement of teaching, there are still problems of mathematics teaching and learning. Igwe, Uzoka, \& Rufai (2013) lamented on the hues and cries of the populace over the continuous poor performance of learners in Nigeria. The populace claimed that educational situation in the country has been blamed predominantly on the poor teachers; teaching skills and methods, teachers' poor attitude to work and lack of teachers' competence. Adeyanju (2013) submitted that very many teachers lack 
demonstrable competence in knowledge and essential pedagogical skills such as lesson plan and activity based learner-centered teaching approach.

Some of the problems in Nigerian educational system are traceable to lack of proper and thorough grasp of concepts by pupils due to their teachers' poor teaching skills. Teaching skills are those actions of skills a teacher adopts during the process of lesson delivery to present the content of the subject matter for easy understanding. According to Multz in Anaekwe et al (2010) sees teaching skills as specific teacher behaviours designed to help the classroom instruction become more effective. These skills include; set induction, reinforcement, stimulus variation, use of example and illustration, explanation, questioning, planned repetition, non-verbal communication and closure (Anaekwe et al, 2010). This paper therefore focused on stimulus variation.

Stimulus variation is an intentional act or purposeful change introduced by a teacher in the course of lesson presentation as to sustain the interest of the learners. Ohuche in Anaekwe et al (2010) stated that stimulus variation is the ability of a teacher to change the environment in such a manner that students are stimulated to learn.Naturally the attention spans of some students are very short and this is particularly noticed when mathematics teaching is ongoing. To maintain the initial interest throughout the classroom interaction, the teacher needs a special skill of stimulus variation (variety and variation) to appeal to the various senses to promote learning. The skill of stimulus variation breaks monotony and reduces boredom thus stimulates interest to the ongoing discussion (Anaekwe et al, 2010). Variety is a spice of life, thus says one adage. The teacher can adopt the use of instructional materials or motivational strategies to introduce a change in the course of the lesson delivery. Stimulus variation as a teaching skill should be used to attract students' attention to the lesson presentation and not to disturb or cause distraction to the lesson.

The skill of stimulus variation deals with presentation of variety of stimulus that can help the learners to overcome boredom in a lesson. It involves changing from time to time. Everyone has a limit to which his attention can be sustained in any given task. Maheshwari (2011) described stimulus variation skill as skillful change in stimuli. The learners are stimulated to increase their active participation. Stimulus variation helps to extend he limit of attention of individuals. Classroom teachers can help learners to remain actively interested in the lesson by varying classroom situation such as teaching style, learning experiences and other teaching behaviors. Some of the specific things that teacher can adopt to ensure the skill of variety and variation are: movement and gesture, different mode of communication, pacing of lesson, change in interactional style and pattern, different mode of reinforcement and change of style in questioning and distribution.

Due to the importance of teaching skills, there have been many researches on teaching skill as a tool for promoting teaching excellence as well as enhancing students' learning experience and satisfaction. For example, Kanno (1986), Ogeyik (2009), Kilic (2010), Chatzidimou (2011), Ghafoor, Kiani, Kayani, \& Kayani (2012), Igwe, Uzoka, \& Rufai (2013), etc. These studies are relevant to the present investigation because they give an insight to what obtains in schools in Nigeria and abroad. None of the researchers that are at the disposal of the present researcher has carried out investigation on stimulus variation. According to Kanno (1986), there was a significant difference in the use of set induction and questioning skills and the researcher suggested that more researchers should go into the study of other teaching skills. The present study is therefore in anticipation to fill the gaps created by previous researchers especially in finding out the extent of emphasizing stimulus variation in mathematics instruction using logistic differential equation as against the usual questionnaire analysis which characterized the previous studies on strategy utilization. 


\section{Logistic Differential Equation}

This paper resorted to the differential equation (model) due to Pierre-Francois Verhulst. This is a model of human population whose rate of change is given as:

$$
\frac{d P}{d t}=P(\alpha-\delta P)
$$

where $\alpha$ and $\delta$ are positive constants and $P$ is the population with time. Equation (1) is called logistic equation, its solution (Equation 2) is called logistic function and the graph is called the logistic curve. Logistic model has proved quite accurate in predicting growth pattern (Ugwu \& Ikpegbu, 2000). Separation of variables is used to solve the logistic equation. Thus, the required solution is given as:

$$
P(t)=\frac{\alpha P_{0}}{\delta P_{0}+\left(\alpha-\delta P_{0}\right) e^{-\alpha t}}
$$

\section{METHOD}

The study adopted a developmental survey design where a cross-section of in-service mathematics teachers in Imo State numbering 94 were continuously observed and on the third day of ascertaining those who emphasize stimulus variation in instruction delivery, eight (8) teachers were found to have emphasized stimulus variation often. The observations were carried out for some days and the data were generated based on direct observational technique (observation schedule). The third day observation was used to predict the rest and comparison was done between the computed and observed data. All the teachers were observed during classroom interactions and personal interviews within the space of 14 days.

\section{RESULT AND DISCUSSION}

Considering the following values $\alpha=94 k, P_{0}=1$ and $\delta=k$, thus from the logistic function, we have the following empirical equation based on data fitting:

$$
P(t)=\frac{94}{1+93 e^{-0.719 t}}
$$

Based on equation (3), the other computed values and observed values of mathematics teachers who emphasized stimulus variation often in the classroom are shown in Table 1.

Table 1. Computed and Observed values

\begin{tabular}{ccc}
\hline $\boldsymbol{t}$ (days) & $\boldsymbol{P}($ Observed) & $\boldsymbol{P}$ (Computed) \\
\hline 4 & 18 & 15 \\
5 & 11 & 26 \\
6 & 17 & 42 \\
7 & 15 & 59 \\
8 & 13 & 73 \\
9 & 14 & 82 \\
10 & 16 & 88 \\
11 & 14 & 91 \\
12 & 13 & 92 \\
13 & 12 & 93 \\
14 & 11 & 94 \\
\hline
\end{tabular}

Source: Researcher's Field Survey, 2017 
Result in Table 1 shows the computed and observed values based on the survey. The table suggests inadequate utilization of stimulus variation by mathematics teachers. The graphical illustration is shown below.

Graphical illustration of observed and computed data

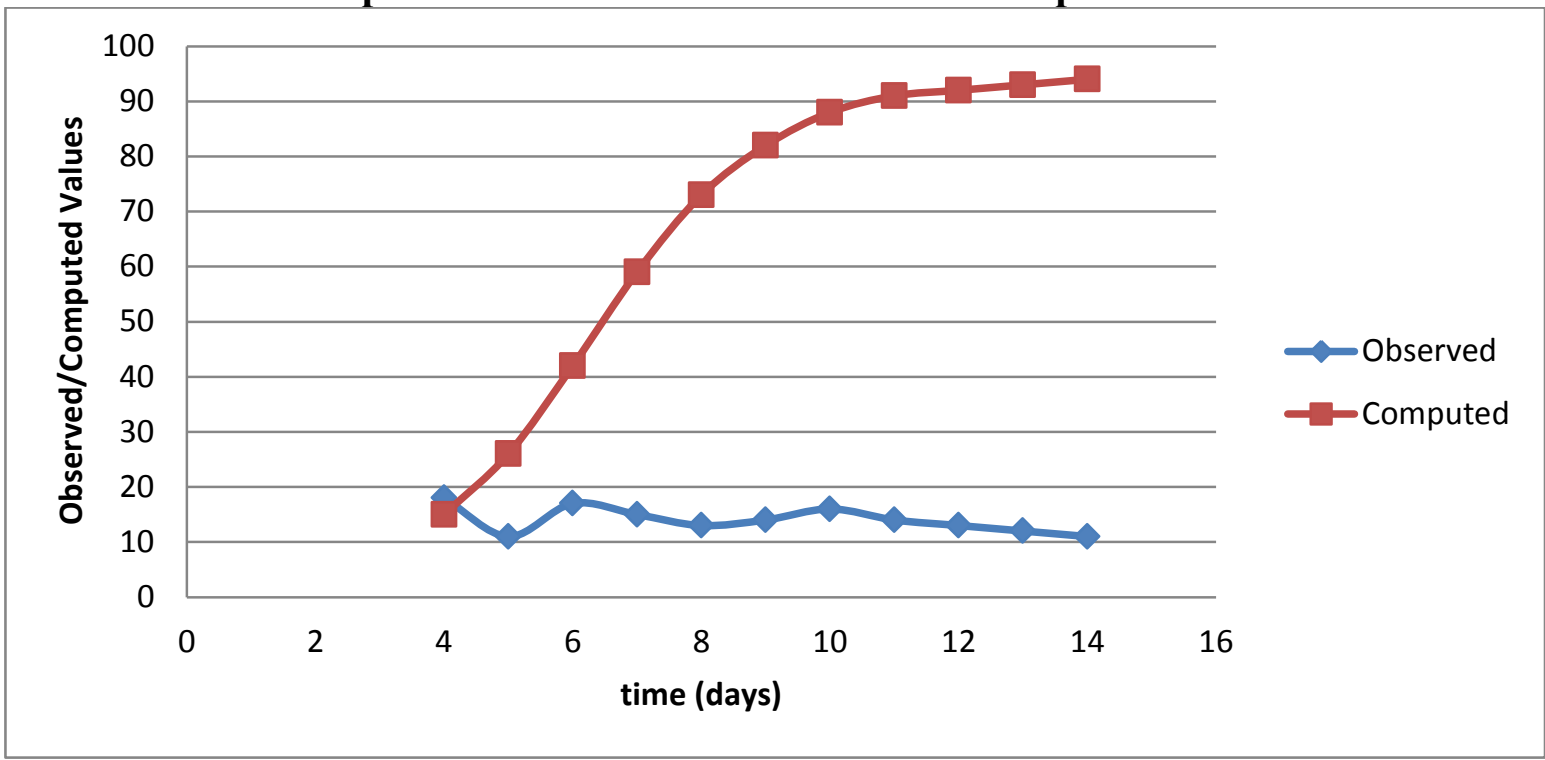

Figure 1. Logistic curve of $P$ (observed/computed) against $t$ (days)

The curve shows decrease and inconsistency in emphasizing stimulus variation by mathematics teachers.

The result from Table 1 and the logistic curve in Figure 1 showed that the observed values and the computed or predicted values never correspond (i.e. diverges), indicating decrease and inconsistency in emphasizing stimulus variation by mathematics teachers. It means that pre-service mathematics teachers seldom emphasize stimulus variation when teaching mathematics. This goes to show inadequate utilization of stimulus variation teaching skill. Thus, it could mean that teachers lack adequate knowledge of stimulus variation or they might have ignore its utilization. This is in agreement with the submission of Ofoefuna (2002) who observed that teachers are not well prepared in Nigeria. Ijaiya (2013) noted that many student teachers fail to acquire enough teaching skills to the detriment of students' learning. The findings of Nwanekezi, Okoli, \& Mezieobi (2011) revealed that if microteaching skills are used, all the strategies for improving students' attitude towards teaching practice would be affected positively.

\section{CONCLUSION}

The teacher needs a special skill of stimulus variation to appeal to the various senses to promote learning. This by implication goes to show that adequate emphasis on stimulus variation would promote teaching excellence and this will enhance students' learning experience and satisfaction in higher education. For one thing, this study has provided a logistic-empirical evidence to support the fact that there is a decreasing and inconsistent utilization of stimulus variation teaching skill. This is an indication of low emphasis of stimulus variation in mathematics instruction. Therefore, mathematics teachers should always employ the skill of stimulus variation in class during instructional delivery so as to enhance students' learning experience and satisfaction thereby promoting teaching excellence. 


\section{REFERENCES}

Adeyanju, T.K. (2013). Quality teacher in every classroom: Prospects and challenges. $A$ Pre-Convocation Guest Lecture at the Maiden Convocation Ceremony for the Award of Nigeria Certificate in Education (NCE) and Conferment of Fellowship; FCT College of Education, Zuba-Abuja.

Anaekwe, M.C., Nzelum, V.N., Olisakwe, S. I., \& Okpala, J. U (2010). Principles and methods of science education. Onitsha: Sofie Publicity and Printry Ltd.

Azuka, B. F. (2015). Mathematics education for sustainable development: Implications to the production and retention of mathematics teachers in Nigerian schools. British Journal of Education, 3(1), 44-51.

Chatzidimou, K. (2011). Microteaching, a 'middle aged' educational innovation: still in fashion? International Conference: The Future of Education: SOE15- chatzidimai. pdf. Foxit Reader.

Ghafoor, A. Kiani, A., Kayani, S., \& Kayani, S. (2012). An exploratory study of microteaching as an effective technology. International Journal of Business and Social Sciences, 3(4), 224-238.

Igwe, R.O., Uzoka, N.E., \& Rufai, S.A. (2013). reflective effects of microteaching and field experiences on pre-service teachers in Nigeria. Asean Journal of Teaching in Higher Education, 5(1), 57-68.

Ijaiya, N.Y.S. (2013). Skill training in teacher education: PDF Document.

Jaja, J. M (2013). Higher education in Nigeria: Its gain, its burden. Global Journal of Human Social Science Linguistics \& Education, 13(14), 21-29.

Kanno, T.N. (Retrieved on April 25, 2013). Transferability of set induction and questioning skills of microteaching to actual teaching practice. Abuja. Nigerian Educational Research and Development Centre.

Kilic, A. (2010). Learner-centred microteaching in teacher education. International Journal of Instruction, 3(1), 77-100.

Kolawole, E., \& Oluwatayo, J. (2004). Mathematics for everyday living. "Implication for Secondary Schools". Mathematical Association of Nigeria (MAN) proceeding of September 2004 National Conferences Sokoto.

Kulbir, S.S. (2006). Teaching of Mathematics. New Delhi: India Sterling Publishers.

Maheshwari, V.K. (2011). Instructional skill of stimulus variation. Retrieved from: www.vkmaheshwari.com.

National Examination Council (NECO) (2016). Chief Examiner's reports (Nigeria) SSCE, May/June examinations.

Nwanekezi, A.U., Okoli, N.T., \& Mezieobi, S.A. (2011). Attitude of student teachers towards teaching practice. Journal of Emerging Trends in Educational Research and Policy Studies (JETERAPS), 2(1), 41-46.

Odili, G.A. (2006). Mathematics in Nigeria Secondary Schools. A Teaching Perspective. Port-Harcourt - Rex - Charles and Patrick Ltd.

Ofoefuna, M.O. (2002). Mediated micro-teaching practicum, A worthwhile innovation in the teacher education program at the university level in Nigeria. Journal of the World Council for Curriculum and Instruction, 3(1), 95-104.

Ogeyik, M.C. (2009). Attitudes of the student teachers in english language teaching programs towards microteaching techniques. English Language Teaching 2(3) 205212. 
Okoye, U.E. (2007). Quality control in teacher production: The case of Nigeria colleges of education. A Book of Proceeding of the National Conference, Faculty of Education, University of Abuja.

Onocha, C.O. (2013). Functional education and graduate employability. A Keynote Address of the 15th National Conference of the Association of Educational Researchers and Evaluators, Nigeria (ASSEREN) held at University of Ilorin, Nigeria on July 8-13 2013.

Tali, D., Mbwas, L., \& Abe, A. (2012). The teaching of mathematics in secondary schools as a tool for self-reliance and re-branding process in Nigeria. Educational Research and Reviews, 7(1), 1-4.

Ugwu, B., \& Ikpegbu, J. (2000). Elementary differential equations. Enugu: Ikenga Publishers.

Unamba, E., \& Obasi, C. (2011). Utilizing ICT in teaching mathematics in secondary schools in Imo State. Alvana Journal of sciences, 5(1), 198-203.

WAEC Chief Examiners Reports (2016). Publication of WACE office, Lagos.

\title{
Aplikasi Persamaan Diferensial Logistik untuk Menyelidiki Derajat Penekanan Variasi Stimulus dalam Instruksi Matematika
}

\author{
Chinedu Obasi * \\ Program Studi Matematika, Sekolah Tinggi Pendidikan Federal Alvan Ikoku, Owerri Imo State, Nigeria \\ Penulis Korespondensi, obasi1212@gmail.com
}

\begin{abstract}
ABSTRAK
Pengetahuan dan keterampilan dalam proses matematika dapat diberikan secara efektif dan sistematis dengan mengajarkan matematika di sekolah. Variasi stimulus sebagai keterampilan mengajar digunakan untuk merangsang minat siswa dan menarik perhatian mereka ke presentasi pelajaran. Oleh karena itu, penelitian ini menyelidiki sejauh mana perlunya variasi stimulus dalam instruksi matematika menggunakan persamaan diferensial logistik. Penelitian ini mengadopsi desain survei perkembangan dengan terus mengamati dan mensurvei guru matematika di Imo State nomor 94 untuk menguraikan sejauh mana mereka menekankan variasi stimulus di kelas untuk mempromosikan keunggulan pengajaran. Observasi dilakukan selama 14 hari dan data dihasilkan berdasarkan teknik observasi langsung (menggunakan jadwal observasi). Hasil menunjukkan bahwa penekanan yang tidak memadai dan tidak konsisten dari variasi stimulus terhadap keterampilan mengajar dalam pembelajaran matematika. Hal ini menyiratkan bahwa guru matematika pra-layanan jarang menekankan variasi stimulus ketika mengajar matematika. Disarankan bahwa guru matematika harus selalu menggunakan keterampilan variasi stimulus di kelas selama penyampaian instruksional sehingga dapat meningkatkan pengalaman belajar siswa dan kepuasan sehingga mempromosikan keunggulan pengajaran.
\end{abstract}

Kata kunci: Pendidikan, matematika, variasi stimulus, persamaan differensial logistik

Diterima 09 Mei 2018

Direvisi 28 Oktober 2018

Disetujui 06 November 2018 